\title{
MODEL MATEMATIKA PENYEBARAN PENYAKIT BAKTERI PUMBULUH KAYU CENGKEH (BPKC)
}

\author{
Chijra1, R. Ratianingsih², dan Hajar ${ }^{3}$ \\ 1,2,3Program Studi Matematika Jurusan Matematika \\ Fakultas Matematika dan IImu Pengetahuan Alam Universitas Tadulako \\ Jalan Soekarno-Hatta Km. 09 Tondo, Palu 94118, Indonesia. \\ 1hijraatjolae@gmail.com,2ratianingsih@yahoo.com, 3hajar.200490@yahoo.com
}

\begin{abstract}
Clove wood vessels is one of the most damaging diseases of clove plants. This disease is caused by the bacterial Ralstonia Syzygii. the bacterial Ras/tonia Syzygii lives in clove wood vessels. The bacterial Ralstonia Syzygii is pread through the Hindola Spp vector. The matemathical model that represents the spread of the disease is developed from the SEI model (Suspectible, Exposed, Infected). The model gives 4 critical points $T_{1}, T_{2}, T_{3}$ and $T_{4}$ exist interaction between bacterial population Ralstonia Syzygii and Hindola Spp vector is less than the level of vulnerable clove recruitman divided by carrying capacity of Ralstonia Syzygii bacterial multiplied by Hindola Spp carrying capacity. The results of system stability analysis at the critical point using linearization give unstable three critical points $T_{1}, T_{2}, T_{3}$ which describes equilibrium conditions and a stable $T_{4}$ critical point which describes endemic conditions. Numerical simulations are carried out to describe temporary disease-free conditions, and stable endemic conditions
\end{abstract}

\section{Keywords $\quad$ : Clove Wood vessel Disease, Linierization Method, SEI Model}

\section{ABSTRAK}

Bakteri Pembuluh Kayu Cengkeh (BPKC) adalah salah satu penyakit yang paling merusak tanaman cengkeh. Penyakit ini disebabkan oleh bakteri Ralstonia Syzygii. Bakteri Ralstonia Syzygii hidup dalam pembuluh kayu cengkeh. Bakteri Ralstonia Syzygii disebarkan melalui vektor Hindola Spp. Model matematika yang merepresentasikan penyebaran penyakit tersebut diadaptasi dari model SEI (Susceptible, Exposed, Infected). Model tersebut memberikan 4 titik kritis $T_{1}, T_{2}, T_{3}$ dan $T_{4}$. Eksistensi $T_{1}, T_{2}, T_{3}$ dapat dijamin eksis sedangkan $T_{4}$ eksis jika interaksi antara populasi bakteri Ralstonia Syzygii dan vektor Hindola Spp kurang dari tingkat recruitman cengkeh rentan dibagi carryng capacity bakteri Ralstonia Syzygii dikali carring capacity Hindola Spp. Hasil dari analisis kestabilan sistem di titik kritis menggunakan liniearisasi memberikan tiga titik kritis $T_{1}, T_{2}, T_{3}$ tidak stabil karena tidak menuju pada kondisi setimbang dan satu titik kritis $T_{4}$ stabil karena menuju pada kondisi setimbang. Simulasi numerik $T_{1}, T_{2}, T_{3}$ menggambarkan kondisi bebas penyakit yang bersifat sementara, serta titik kritis $T_{4}$ menggambarkan kondisi endemik yang stabil bersifat menetap.

\section{Kata Kunci $\quad$ : Penyakit Bakteri Pembuluh Kayu Cengkeh (BPKC), Metode Linearisasi, Model SEI}




\section{PENDAHULUAN}

\subsection{Latar Belakang}

Cengkeh (Syzygium aromaticum) merupakan tanaman asli Indonesia yang tergolong ke dalam keluarga tanaman Myrtaceae pada ordo Myrtales. Cengkeh juga merupakan salah satu komoditas pertanian yang tinggi nilai ekonominya yang pemanfaatannya digunakan sebagai rempah-rempah dan obat tradisional untuk analgesik (mengurangi rasa nyeri). Pada daun cengkeh mengandung senyawa eugenol, eugenol asetat dan caryophylene. Kadar eugeno/ dalam minyak atsiri daun cengkeh umumnya antara $80-88 \%$. Senyawa eugeno/ ini dapat berkhasiat sebagai antibakteri. Dalam kesehatan digunakan sebagai antiseptik dan anastesi lokal (Nurdjannah, 2004). Peran cengkeh sebagai bahan baku tersebut membuat ketersediaan bahan baku cengkeh perlu untuk diperhatikan.

Penyakit BPKC disebabkan oleh suatu bakteri yang terdapat yaitu bakteri Ralstonia Syzygii. Bakteri ini memiliki kemampuan persisten dan bermultipikasi didalam tubuh serangga Hindola spp yang berperan sebagai vektor yang menyebarkan penyakit BPKC. Bakteri Ralstonia Syzygii disebarkan oleh serangga Hindola spp yang mendapatkan makanan dengan jalan menghisap cairan dari pembuluh kayu pada tanaman cengkeh sakit. Serangga Hindola SPP menghisap Bakteri Ralstonia Syzygii dengan jalan makan daun tanaman cengkeh sakit dan serangga Hindola Spp menularkan bakteri Ralstonia Syzygï dengan jalan berterbangan dan makan pada tanaman sehat. Serangga Hindola Spp adalah serangga penghisap yang hidup pada pembuluh kayu, yang masuk ke dalam batang cengkeh dengan mengebor batang tanaman cengkeh. Serangga Hindola spp mampu hidup selama berbulanbulan pada tanaman cengkeh, dan mampu menyebarkan penyakit BPKC dalam waktu beberapa hari (Eden-green et al.,1992).

Tanaman cengkeh terinfeksi dimulai dari terjadinya infeksi patogen ke dalam akar, baik secara sendiri maupun melalui luka yang dibuat oleh serangga dan alat-alat pertanian. Setelah berhasil masuk ke dalam jaringan akar, Bakteri Ralstonia Syzygii akan berkembang biak di dalam pembuluh kayu (xylem) dalam akar dan pangkal batang, kemudian menyebar ke seluruh bagian tanaman. Akibat tersumbatnya pembuluh kayu oleh sel bakteri Ralstonia Syzygii, transportasi air dan mineral dari tanah terhambat sehingga tanaman menjadi layu dan mati. Tanaman cengkeh yang terinfeksi Bakteri Ralstonia Syzygii akan menunjukkan gejala daun menguning dan layu, serta eksudat bakteri berwarna putih susu atau putih kemerahan pada rimpang, akar, batang, atau ranting. Apabila ujung potongan tersebut dicelupkan ke dalam air jernih maka akan keluar secara perlahan-lahan cairan berwarna putih seperti kabut asap (Supriadi et al. 1995). 
Serangga Hindola spp merupakan serangga pengisap pada pembuluh kayu dan berasosiasi erat dengan tanaman cengkeh. Serangga Hindola Spp selalu ditemukan pada tanaman cengkeh sehat. Serangga Hindola spp hanya ditemukan pada bagian-bagian tanaman cengkeh yang masih muda, yaitu pada pucuk/ranting muda, semakin lama serangga Hindola spp makan tanaman cengkeh yang sakit maka semakin banyak bakteri Ralstonia Syzygii yang dikandungnya (Balfas, R. Dkk 1989).

Penelitian ini akan membangun model matematika penyebaran penyakit BPKC pada tanaman cengkeh. Model matematika penyebaran penyakit BPKC yang melibatkan serangga Hindola Spp sebagai vektor penyebar dan pembawa bakteri dibangun berdasarkan interaksi antara Hindola Spp dan tanaman cengkeh. Analisa kestabilan model tersebut selanjutnya dikaji di sekitar titik kritis yang merepresentasikan kondisi bebas penyakit dan endemik dengan menggunakan metode Linearisasi.

\subsection{Rumusan Masalah}

Berdasarkan paparan pada latar belakang, maka permasalahan yang dirumuskan dalam penelitian ini sebagai berikut:

1. Bagaiman model penyebaran penyakit BPKC dengan serangga Hindola spp sebagai vektor.

2. Bagaimana kestabilan model penyebaran penyakit BPKC pada tanaman cengkeh dengan menggunakan metode linierisasi.

\subsection{Tujuan Penelitian}

Adapun tujuan dari penelitian ini adalah:

1. Mendapatkan model penyebaran penyakit BPKC yang dibawa oleh Hindola spp.

2. Mendapatkan analisa kestabilan model penyebaran penyakit BPKC pada tanaman cengkeh dengan metode linierisasi.

\subsection{Asumsi Penilitian}

Asumsi yang digunakan dalam penelitian ini adalah

1. Tanaman cengkeh yang terinfeksi penyakit BPKC tidak dapat disembuhkan.

2. Serangga Hindola spp dan Bakteri Ralstonia Syzygii diasumsikan mengikuti model pertumbuhan logistik.

3. Serangga Hindola spp diasumsikan menyerang tanaman cengkeh telah membawa Bakteri Ralstonia Syzygii. 


\section{METODE PENELITIAN}

Berikut merupakan prosedur yang digunakan dalam penelitian ini yaitu:

1. Memulai penelitian untuk membangun model matematika penyebaran penyakit BPKC

2. Mengkaji literatur berupa buku, artikel dan jurnal untuk membangun model matematika penyebaran penyakit BPKC

3. Membangun model matematika penyebaran penyakit Bakteri Pembuluh Kayu Cengkeh pada tanaman cengkeh.

4. Menentukan titik kritis dari persamaan model matematika penyebaran penyakit BPKC

5. Menganalisis kestabilan dari persamaan model matematika penyebaran penyakit BPKC

6. Melakukan simulasi kestabilan dari persamaan model matematika penyebaran BPKC

7. Menyimpulkan hasil penelitian.

8. Selesai

\section{HASIL DAN PEMBAHASAN}

\subsection{Konstruksi Model Matematika Penyebaran Penyakit (BPKC)}

Model dinamik dari penyebaran penyakit BPKC pada tanaman cengkeh dibangun berdasarkan asumsi-asumsi dan diadaptasikan dari model SEI yang mengacu pada kelompok populasi tananam cengkeh susceptible (rentan), exposed (laten) dan infected (infeksi). Terdapat 5 populasi yang diamati yaitu kelompok populasi serangga Hindola Spp $(H)$, populasi Bakteri Ralstonia Syzygii( $(B)$, Populasi tanaman cengkeh rentan $\left(S_{c}\right)$, populasi tanaman cengkeh yang sudah terinfeksi bakteri Ralstonia Syzygii tapi belum mampu menginfeksi $\left(E_{c}\right)$, dan populasi tanaman cengkeh yang terinfeksi $\left(I_{c}\right)$.

Model penyebaran penyakit BPKC dibangun berdasarkan perubahan banyaknya populasi setiap subpopulasi relatif terhadap waktu. Pada populasi rentan $S_{c}$ terdapat rekruitmen awal tanaman cengkeh rentan $A$ yang mempengaruhi banyaknya populasi tanaman cengkeh rentan. Terjadi transisi anggota subpopulasi cengkeh $S_{c}$ berpindah ke subpopulasi $E_{c}$ disebabkan adanya interaksi antara subpopulasi bakteri Ralstonia Syzygii dan subpopulasi vektor Hindola Spp dengan laju infeksi Hindola Spp sebesar $\alpha$. Terjadi pula transfer anggota subpopulasi $E_{c}$ ke dalam subpopulasi $I_{c}$ sebesar $\delta$.

Tingkat kematian alami pada tanaman cengkeh sebesar $\mu_{1}$, dan tingkat kematian akibat penyakit BPKC yaitu $\mu_{2}$ diperhitungkan sebagai faktor yang mempengaruhi laju berkembangnya populasi rentan seiring dengan perkembangan waktu. Pertumbuhan bakteri Ralstonia Syzygii (B) didukung oleh adanya suplai makanan yang berasal dari nutrisi tanaman 
cengkeh yang memberikan daya dukung pertumbuhan logistik sebesar $r_{1} B\left(1-\frac{B}{K_{1}}\right)$ dimana $K_{1}$ adalah Carryng capacity bakteri Ralstonia Syzygii. pertumbuhan Hindola Spp juga didukung pertumbuhan logistik sebesar $r_{2} H\left(1-\frac{H}{K_{2}}\right)$ dimana $K_{2}$ adalah Carryng capacity Hindola Spp.

Terjadi transisi subpopulasi $S_{c}$ ke subpopulasi $E_{c}$ akibat berinteraksi dengan subpopulasi Hindola Spp yang berperan sebagai penyebar bakteri Ralstonia Syzygii. Terdapat pula transisi anggota subpopulasi $E_{c}$ ke subpopulasi $I_{c}$ sebesar $\delta$ terjadi akibat Bakteri Ralstonia Syzygii yang masuk kedalam subpopulasi tanaman cengkeh ekspose semakin berkembang serta menginfeksi secara penuh dan menyebabkan kematian pada tanaman cengkeh.

Berdasarkan fenomena tersebut diagram penyebaran penyakit BPKC pada tanaman cengkeh diperlihatkan pada Gambar 1.

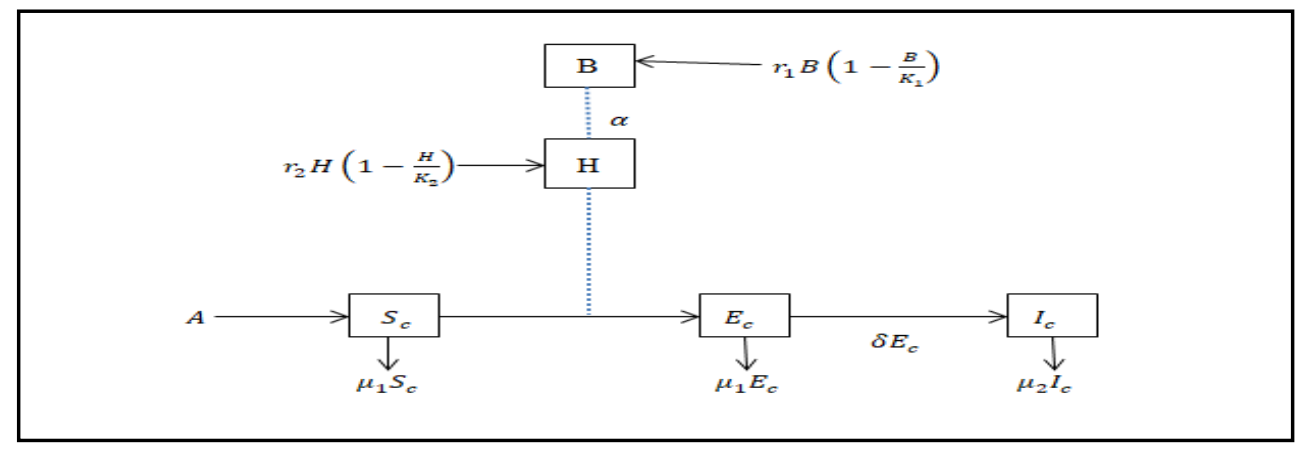

Gambar 1: Diagram Penyebaran Penyakit BPKC

Dari diagram kompartemen penyebaran penyakit BPKC pada Gambar 1, diturunkan sistem persamaan diferensial dari persamaan-persamaan yang merepresentasikan laju perubahan masing-masing populasi sehingga model dari penyebaran penyakit BPKC pada tanaman cengkeh dinyatakan pada persamaan 1 sampai 5 .

$\frac{d B}{d t}=r_{1} B\left(1-\frac{B}{K_{1}}\right)$
$\frac{d H}{d t}=r_{2} H\left(1-\frac{H}{K_{2}}\right)$
$\frac{d S_{c}}{d t}=A-\alpha \cdot B \cdot H-\mu_{1} S_{c}$
$\frac{d E_{c}}{d t}=\alpha \cdot B \cdot H-\delta E_{c}-\mu_{1} E_{c}$
$\frac{d I_{c}}{d t}=\delta E_{c}-\mu_{2} I_{c}$ 
Tabel 1 : Deskripsi Parameter

\begin{tabular}{|c|l|c|c|}
\hline Parameter & \multicolumn{1}{|c|}{ Deskripsi } & Nilai & Sumber (referensi) \\
\hline$A$ & Tingkat rekruitmen cengkeh rentan & 100 & Asumsi \\
\hline$\mu_{1}$ & Laju kematian alami pada tanaman cengkeh & 0,142857 & $\frac{1}{\text { lifetime }}$ \\
\hline$\mu_{2}$ & $\begin{array}{l}\text { Laju kematian penyakit BPKC pada tanaman } \\
\text { cengkeh }\end{array}$ & 0,3112 & $\begin{array}{c}\text { Venechoute } \text { et al } \\
(2003)\end{array}$ \\
\hline$\delta$ & Laju transisi cengkeh ekspose ke infeksi & 0,014 & Asumsi \\
\hline$r_{1}$ & Tingkat kelahiran bakteri Ralstonia Syzygii & 0,0238 & Asumsi \\
\hline$r_{2}$ & Tingkat kelahiran vektor Hindola Spp & 0,0147 & Asumsi \\
\hline$K_{1}$ & Carryng capacity bakteri Ralstonia Syzygii & 2000 & Asumsi \\
\hline$K_{2}$ & Carryng capacity vektor Hindola Spp & 2000 & Asumsi \\
\hline$\alpha$ & $\begin{array}{l}\text { Tingkat interaksi antara populasi bakteri Ralstonia } \\
\text { Syzygii dan Hindola Spp }\end{array}$ & 0,0000012 & Asumsi sesuai syarat \\
\hline
\end{tabular}

\subsection{Analisis Kestabilan Matematikapenyebaran Penyakit Bakteri Pembuluh Kayu Cengkeh}

Titik kritis diperoleh dari sistem persamaan (1)-(5) yaitu dimana $\frac{d B}{d t}=0, \frac{d H}{d t}=0, \frac{d S_{c}}{d t}=$ $0, \frac{d E_{c}}{d t}=0, \frac{I_{c}}{d t}=0$ sehingga diperoleh persamaan 6 sampai 10 .

$$
\begin{aligned}
& \frac{d B}{d t}=r_{1} B\left(1-\frac{B}{K_{1}}\right) \\
& \frac{d H}{d t}=r_{2} H\left(1-\frac{H}{K_{2}}\right) \\
& \frac{d S_{c}}{d t}=A-\alpha \cdot B \cdot H-\mu_{1} S_{c} \\
& \frac{d E_{c}}{d t}=\alpha \cdot B \cdot H-\delta E_{c}-\mu_{1} E_{c} \\
& \frac{d I_{c}}{d t}=\delta E_{c}-\mu_{2} I_{c}
\end{aligned}
$$

Dari persaman (6),(7),(8),(9), dan (10) diperoleh titik kritis pertama yang menggambarkan kondisi bebas penyakit karna Hindola Spp dan Bakteri Ralstonia Syzygii tidak eksis yaitu :

$T_{1}=\left(Z, E_{c}^{*} I_{c}^{*}, B^{*}, H^{*}\right)=\left(\frac{A}{\mu_{1}}, 0,0,0,0\right)$

Titik kritis kedua yang menggambarkan kondisi bebas penyakit dimana tanaman cengkeh dapat hidup bersama dengan Hindola Spp yaitu:

$T_{2}=\left(Z, E_{c,}^{*} I_{c}^{*}, B^{*}, H^{*}\right)=\left(\frac{A}{\mu_{1}}, 0,0, K_{2}, 0\right)$ 
Titik kritis ketiga yang menggambarkan kondisi dimana pola tanaman cengkeh hidup bersama dengan Bakteri Ralstonia Syzygii yaitu:

$T_{3}=\left(Z, E_{c}^{*} I_{c}^{*}, B^{*}, H^{*}\right)=\left(\frac{A}{\mu_{1}}, 0,0,0, K_{1}\right)$

Hal ini memberikan arti bahwa penyakit BPKC pada tanaman cengkeh tersebut bukan disebabkan oleh Hindola Spp namun disebabkan oleh faktor abiotik.

Titik kritis keempat yang menggambarkan kondisi endemik yaitu:

$T_{4}=\left(Z, E_{c,}^{*} I_{c}^{*}, B^{*}, H^{*}\right)=\left(\frac{A-\alpha K_{1} K_{2}}{\mu_{1}}, \frac{\alpha K_{1} K_{2}}{\mu_{1}+\delta}, \frac{\alpha K_{1} K_{2}}{\left(\mu_{1}+\delta\right) \mu_{1}}, K_{1}, K_{2}\right)$

\subsection{Syarat Eksistensi Titik Kritis}

Untuk menjamin eksistensi suatu populasi, diperlukan suatu syarat eksistensi yaitu banyaknya populasi pada setiap kompartemen yaitu $S_{c}, E_{c}, I_{c}, B, H$ bernilai nonnegatif. Persamaan (1)-(5) yang memiliki empat titik kritis dengan parameter-parameter bernilai positif, yaitu $A, \mu_{1}, \mu_{2}, \delta, \alpha, K_{1}, K_{2}, r_{1}, r_{2}$. Eksistensi titik kritis bebas penyakit $T_{1}=\left(\frac{A}{\mu_{1}}, 0,0,0,0\right)$ dapat dijamin eksistensinya karena $S_{c}=\frac{A}{\mu_{1}}$ bernilai nonnegatif. Titik kritis $T_{2}=\left(\frac{A}{\mu_{1}}, 0,0, K_{2}, 0\right)$ dapat dijamin eksistensinya karena $S_{c}=\frac{A}{\mu_{1}}$ dan $H=K_{2}$ bernilai nonegatif. . Titik kritis $T_{3}=$ $\left(\frac{A}{\mu_{1}}, 0,0,0, K_{1}\right)$ dapat dijamin eksistensinya karena $S_{c}=\frac{A}{\mu_{1}}$ dan $B=K_{1}$ bernilai nonegatif. Sedangkan tTitik kritis yang menggambarkan kondisi endemik $T_{4}=$ $\left(\frac{A-\alpha K_{1} K_{2}}{\mu_{1}}, \frac{\alpha K_{1} K_{2}}{\mu_{1}+\delta}, \frac{\alpha K_{1} K_{2}}{\left(\mu_{1}+\delta\right) \mu_{1}}, K_{1}, K_{2}\right)$ dapat dijamin eksistensinya jika $\alpha<\frac{A}{K_{1} K_{2}}$ Hal ini memberikan arti bahwa untuk tercapainya kondisi endemik tingkatkan interaksi antara populasi bakteri Ralstonia Syzygii dan Hindola Spp tidak boleh melalui ambang batas sebesar $\frac{A}{K_{1} K_{2}}$.

\subsection{Analisis Kestabilan}

\subsubsection{Analisis Kestabilan Titik Kritis $T_{1}$}

Titik kritis $T_{1}$ yang merepresentasikan kondisi bebas penyakit bukan titik nol, maka dilakukan transformasi. Untuk menjamin kestabilannya diperlukan nilai eigen $\lambda$ yang diperoleh dari matriks Jacobi. Matriks Jacobi dari sistem persamaan diferensial (6)-(10) yang dievaluasi pada $T_{1}$ memberikan persamaan karakteristik dalam $\lambda$ diperlihatkan pada persamaan (11) :

$-\left(-\mu_{1}-\lambda\right)\left(-\mu_{1}-\delta-\lambda\right)\left(\mu_{2}+\lambda\right)\left(-r_{2}+\lambda\right)\left(-r_{1}+\lambda\right)=0$

Dari persamaan (11) diperoleh nilai eigen :

$\lambda_{1}=-\mu_{1}, \lambda_{2}=-\mu_{1}-\delta, \lambda_{3}=-\mu_{2}, \lambda_{4}=r_{2}, \lambda_{5}=r_{1}$

karna $\lambda_{4}$ dan $\lambda_{5}$ bernilai positif, maka dapat disimpulkan bahwa $T_{1}$ tidak stabil.

\subsubsection{Analisis Kestabilan Titik Kritis $T_{2}$}

Karena titik kritis $T_{2}=\left(\frac{A}{\mu_{1}}, 0,0,0, K_{1}\right)$ bukan titik kritis nol, maka dilakukan transformasi Untuk menjamin kestabilannya diperlukan nilai eigen $\lambda$ yang diperoleh dari 
matriks Jacobi. Matriks Jacobi dari sistem persamaan diferensial (6)-(10) yang dievaluasi pada $T_{2}$ memberikan persamaan karakteristik dalam $\lambda$ diperlihatkan pada persamaan (12) :

$\left(-\mu_{1}-\lambda\right)\left(-\mu_{1}-\delta-\lambda\right)\left(\mu_{2}+\lambda\right)\left(r_{2}+\lambda\right)\left(-r_{1}+\lambda\right)$

Dari persamaan (12) diperoleh nilai :

$\lambda_{1}=-\mu_{1}, \lambda_{2}=-\mu_{1}-\delta, \lambda_{3}=-\mu_{2}, \lambda_{4}=-r_{2}, \lambda_{5}=r_{1}$

Karena $\lambda_{5}$ bernilai positif maka dapat disimpulkan bahwa $T_{2}$ tidak stabil.

\subsubsection{Analisis Kestabilan Titik Kritis $T_{3}$}

Pada titik kritis $T_{3}=\left(\frac{A}{\mu_{1}}, 0,0,0, K_{1}\right)$ bukan titik kritis nol, maka dilakukan transformasi Untuk menjamin kestabilannya diperlukan nilai eigen $\lambda$ yang diperoleh dari matriks Jacobi. Matriks Jacobi dari sistem persamaan diferensial (6)-(10) yang dievaluasi pada $T_{3}$ memberikan persamaan karakteristik dalam $\lambda$ diperlihatkan pada persamaan (13) :

$\left(-\mu_{1}-\lambda\right)\left(-\mu_{1}-\delta-\lambda\right)\left(\mu_{2}+\lambda\right)\left(-r_{2}+\lambda\right)\left(r_{1}+\lambda\right)=0$

Dari persamaan (13) diperoleh nilai eigen :

$\lambda_{1}=-\mu_{1}, \lambda_{2}=-\mu_{1}-\delta, \lambda_{3}=-\mu_{2}, \lambda_{4}=r_{2}, \lambda_{5}=-r_{1}$

Karena $\lambda_{4}$ bernilai positif maka dapat disimpulkan bahwa $T_{3}$ tidak stabil.

\subsubsection{Analisis Kestabilan Titik Kritis $T_{4}$}

Pada titik kritis $T_{4}=\left(\frac{A-\alpha K_{1} K_{2}}{\mu_{1}}, \frac{\alpha K_{1} K_{2}}{\mu_{1}+\delta}, \frac{\alpha K_{1} K_{2}}{\left(\mu_{1}+\delta\right) \mu_{1}}, K_{1}, K_{2}\right)$ bukan titik kritis nol, maka dilakukan transformasi Untuk menjamin kestabilannya diperlukan nilai eigen $\lambda$ yang diperoleh dari matriks Jacobi. Matriks Jacobi dari sistem persamaan diferensial (6)-(10) yang dievaluasi pada $T_{4}$ memberikan persamaan karakteristik dalam $\lambda$ dipeerlihatkan pada persamaan (14):

$-\left(-\mu_{1}-\lambda\right)\left(-\mu_{1}-\delta-\lambda\right)\left(\mu_{2}+\lambda\right)(r+\lambda)^{2}=0$

Dari persamaan (14) diperoleh nilai eigen :

$\lambda_{1}=-\mu_{1}, \lambda_{2}=-\mu_{1}-\delta, \lambda_{3}=-\mu_{2}, \lambda_{4}=-r_{2}, \lambda_{5}=-r_{1}$

Karena $\lambda_{1}, \lambda_{2}, \lambda_{3}, \lambda_{4}$, dan $\lambda_{5}$ bernilai negatif maka dapat disimpulkan bahwa $T_{4}$ stabil.

Dari analisa kestabilan terhadap empat titik kritis dinyatakan bahwa $T_{1}, T_{2}, T_{3}$ tidak stabil dan $T_{4}$ stabil.

Identifikasi syarat eksis dan syarat stabil titik kritis dinyatakan dalam Tabel 2 sebagai berikut : 
Tabel 2: Syarat Eksis dan Syarat Stabil Titik Kritis

\begin{tabular}{|c|c|l|}
\hline Titik Kritis & Syarat Eksis & Kestabilan \\
\hline$T_{1}$ & - & Tidak stabil \\
\hline$T_{2}$ & - & Tidak stabil \\
\hline$T_{3}$ & - & Tidak stabil \\
\hline$T_{4}$ & $\alpha<\frac{A}{K_{1} K_{2}}$ & stabil \\
\hline
\end{tabular}

\subsection{Simulasi}

\subsubsection{Simulasi Kondisi Bebas Penyakit $T_{1}$}

Simulasi kondisi bebas penyakit untuk titik kritis $T_{1}$ dilakukan dengan menggunakan nilai awal $S_{c}(0)=500, E_{c}(0)=300, I_{c}(0)=200, H(0)=200, B(0)=1800$ dengan interval waktu 750 hari. Gambar (2.a) mempresentasikan pertumbuhan subpopulasi tanaman cengkeh rentan yang meningkat hingga mencapai 694 pohon. Penurunan jumlah subpopulasi cengkeh rentan disebabkan oleh populasi bakteri Ralstonia Syzygii dan populasi vektor Hindola Spp yang terus mengalami penurunan jumlah subpopulasi. Gambar (2.b) memperlihatkan subpopulasi cengkeh ekspose mengalami penurunan jumlah subpopulasi seiring dengan bertambahnya waktu. Penurunan jumlah subpopulasi cengkeh ekspose disebabkan ketidak beradaan populasi bakteri Ralstonia syzygii. Gambar (2.c) juga memperlihatkan subpopulasi cengkeh infeksi mengalami penurunan subpopulasi disebabkan tidak adanya transisi subpopulasi cengkeh ekspose ke cengkeh infeksi. Gambar (2.e) memperlihatkan menurunnya jumlah populasi Bakteri Ralstonia Syzygii hingga mencapai 14 populasi dalam kurun waktu 739 hari. Gambar (2.d) memperlihatkan menurunnya subpopulasi vektor Hindola Spp sebagai penyebar penyakit BPKC.

Ketidakstabilan titik kritis $T_{1}$ terlihat pada Gambar (4.2.1e) dimana populasi bakteri Ralstonia Syzygii tidak konvergen kenilai $K_{1}=0$. Gambar tersebut memperlihatkan bahwa banyaknya populasi bakteri Ralstonia Syzygii yang dapat bertahan konvergen ke 14, bukan ke nol. Gambar (2.d) juga memperlihatkan populasi Hindola Spp tidak konvergen kenilai $K_{2}=0$, karena populasi Hindola yang dapat bertahan sebanyak 2 populasi. 


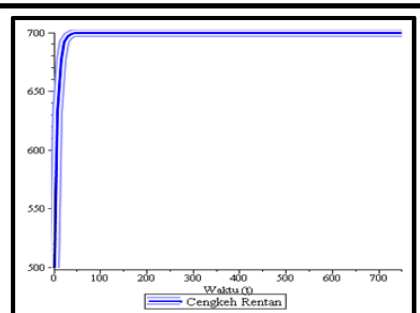

(a)

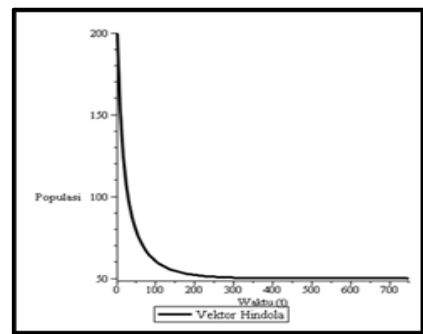

(d)

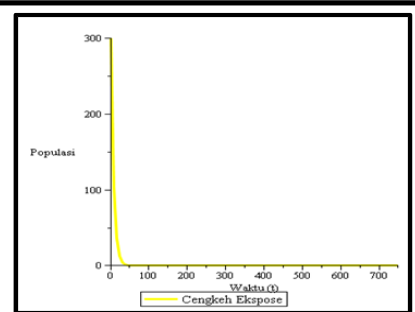

(b)

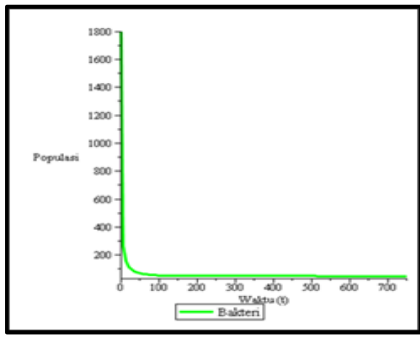

(e)

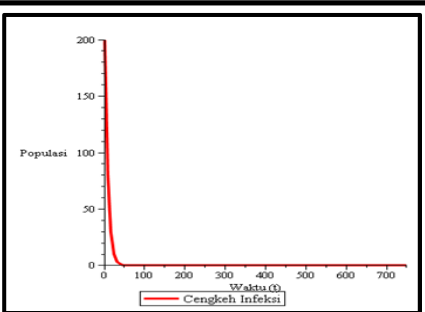

(c)

Gambar 2 : Kondisi Bebas Penyakit $T_{1}$

\subsubsection{Simulasi Kondisi Bebas Penyakit $T_{2}$}

Simulasi kondisi bebas penyakit untuk titik kritis $T_{2}$ dilakukan dengan menggunakan nilai awal $S_{c}(0)=500, E_{c}(0)=200, I_{c}(0)=300, H(0)=700, B(0)=1000$ dengan interval waktu 750 hari. Gambar (3.a) mempresentasikan pertumbuhan subpopulasi cengkeh rentan mengalami peningkatan hingga mencapai 700 pohon. Gambar (3.b) memperlihatkan subpopulasi cengkeh ekspose mengalami penurunan jumlah subpopulasi disebabkan menurunnya populasi bakteri Ralstonia Syzygii. Gambar (3.c) juga memperlihatkan subpopulasi cengkeh infeksi mengalami penurunan jumlah subpopulasi disebabkan tidak adanya transisi subpopulasi cengkeh ekspose ke cengkeh infeksi. Gambar (3.e) memperlihatkan menurunnya jumlah subpopulasi Bakteri Ralstonia Syzygii hingga mencapai 14 populasi seiring dengan bertambahnya waktu. Gambar (3.d) jumlah subpopulasi vektor Hindola Spp mengalami pertambahan jumlah subpopulasi sebanyak 876 dalam kurun waktu 411 hari. Selanjutnya subpopulasi tersebut berjumlah tetap setelah melewati 411 hari.

Ketidakstabilan titik kritis $T_{2}$ terlihat pada Gambar (3.e) dimana populasi bakteri Ralstonia Syzygii tidak konvergen kenilai $K_{1}=0$. Gambar tersebut memperlihatkan bahwa banyaknya populasi bakteri Ralstonia Syzygii yang dapat bertahan konvergen ke 14, bukan ke nol. 


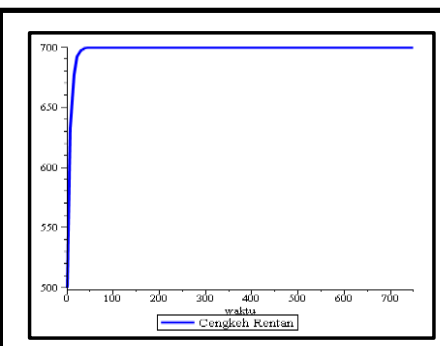

(a)

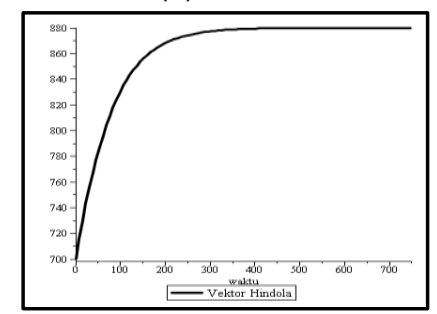

(d)

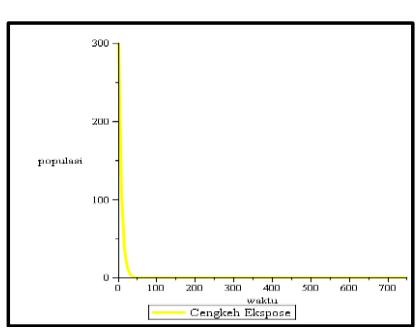

(b)

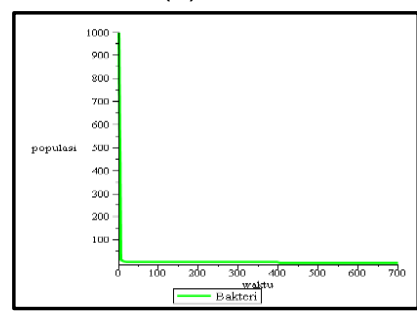

(e)

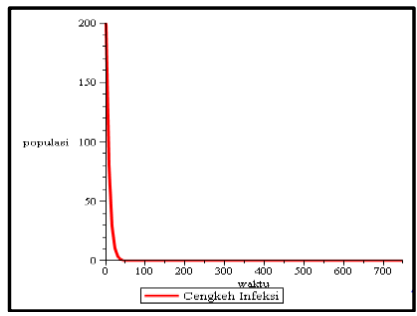

(c)

Gambar 3 : Kondisi Bebas Penyakit $T_{2}$

\subsubsection{Simulasi Kondisi Bebas Penyakit $T_{3}$}

Simulasi kondisi bebas penyakit untuk titik kritis $T_{3}$ dilakukan dengan menggunakan nilai awal $S_{c}(0)=500, E_{c}(0)=200, I_{c}(0)=300, H(0)=200, B(0)=1800$ dengan interval waktu 750 hari. Gambar (4.a) memperlihatkan bahwa sub populasi cengkeh rentan akan terus mengalami peningkatan hingga mencapai 699 pohon. Gambar (4.b) memperlihatkan subpopulasi cengkeh ekspose mengalami penurunan jumlah subpopulasi seiring dengan bertambahnya waktu. Menurunnya subpopulasi ekspose tersebut disebabkan karena tetapnya jumlah populasi bakteri Ralstonia Syzygii sebagai penginfeksi meskipun seiring terjadinya pertambahan waktu. Gambar (4.c) juga memperlihatkan subpopulasi cengkeh infeksi mengalami penurunan subpopulasi seiring dengan bertambahnya waktu. Penurunan jumlah subpopulasi cengkeh infeksi disebabkan tidak adanya transisi subpopulasi cengkeh ekspose ke cengkeh infeksi. Gambar (4.d) memperlihatkan penurunan populasi pada Hindola Spp hingga mencapai 2 populasi seiring bertambahnya waktu. Gambar (4.e) memperlihatkan populasi bakteri Ralstonia Syzygii akan mengalami kenaikan hingga mencapai 1998 dalam waktu 265 hari. Selanjutnya populasi bakteri Ralstonia Syzygii akan menuju ke nilai carriying capacity.

Ketidak stabilan titik kritis $T_{3}$ terlihat pada Gambar 4.d dimana populasi Hindola Spp tidak konvergen kenilai $K_{2}=0$. Gambar tersebut memperlihatkan bahwa banyaknya populasi Hindola yang dapat bertahan konvergen ke 2, bukan ke nol. 


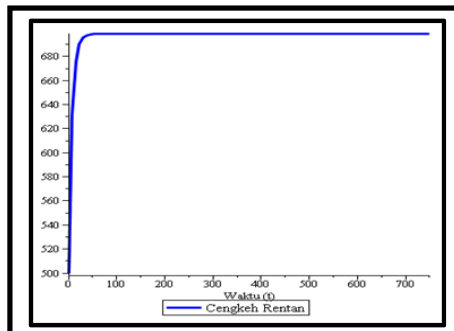

(a)

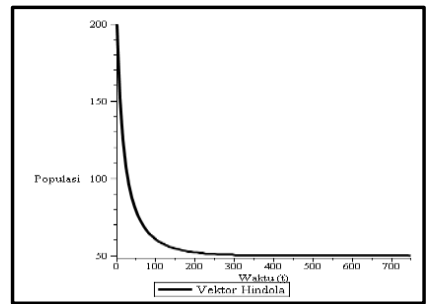

(d)

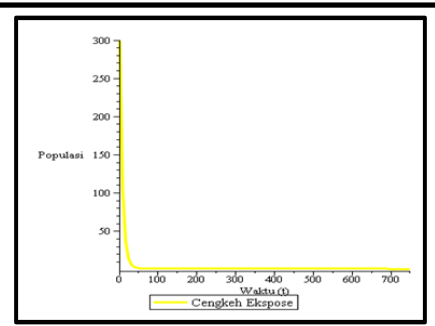

(b)

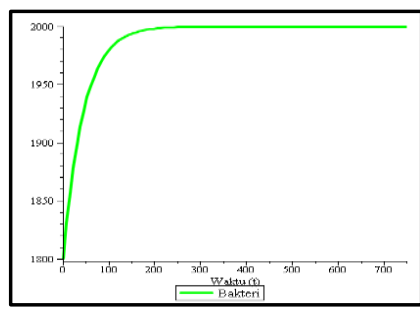

(e)

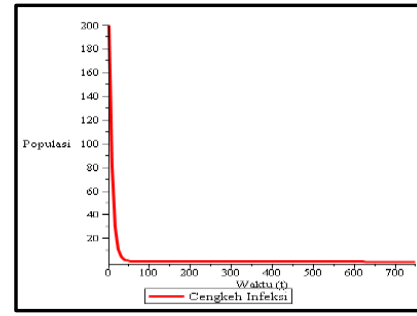

(c)

Gambar $4:$ kondisi bebas penyakit $T_{3}$

\subsubsection{Simulasi Kondisi endemik $T_{4}$}

Simulasi kondisi endemik untuk titik kritis $T_{4}$ dengan menggunakan nilai awal $S_{c}(0)=900, E_{c}(0)=800, I_{c}(0)=700, H(0)=700, B(0)=1000$ dengan interval waktu 750 hari. Gambar (5.a) memperlihatkan terjadinya penurunan banyaknya subpopulasi cengkeh rentan hingga mencapai 552 pohon dalam kurun waktu 431 hari. Penurunan jumlah subpopulasi cengkeh rentan setelah waktu tersebut disebabkan oleh populasi bakteri Ralstonia syzygii sebagai penginfeksi yang terus mengalami pertambahan jumlah populasi sebanyak 1996 dalam kurun waktu 251 hari dan mendekati konstan setelah waktu tertentu. Populasi bakteri Ralstonia syzygii juga didukung oleh populasi vektor Hindola $s p$ yang juga mengalami pertambahan jumlah populasi sebanyak 877 dalam kurun waktu 384 hari. Menurunnya jumlah subpopulasi cengkeh rentan juga dipengaruhi oleh laju kematian alaminya sendiri. Gambar (5.b) memperlihatkan jumlah subpopulasi cengkeh ekspose mengalami penurunan jumlah sub populasi hingga mencapai 55 pohon setelah melewati 130 hari. Penurunan jumlah subpopulasi cengkeh ekspose dipengaruhi oleh terjadinya laju transisi dari subpopulasi cengkeh ekspose ke subpopulasi cengkeh infeksi dan dipengaruhi oleh laju kematian alaminya sendiri. Gambar (5.c) juga memperlihatkan terjadi laju transisi dari subpopulasi cengkeh ekspose ke subpopulasi cengkeh infeksi yang menyebabkan subpopulasi cengkeh infeksi bertambah hingga mencapai 791 pohon dalam waktu 30 hari. Selanjutnya terjadi penurunan pada subpopulasi cengkeh infeksi hingga mencapai 120 pohon setelah melewati 495 hari yang disebabkan adanya kematian penyakit BPKC. 


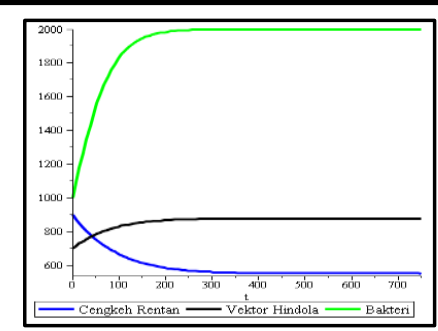

(a)

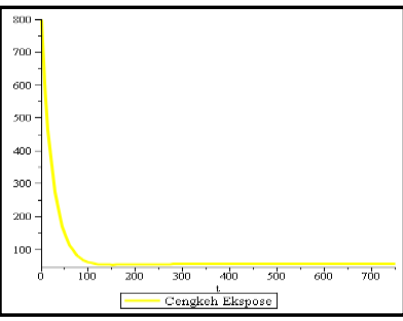

(b)

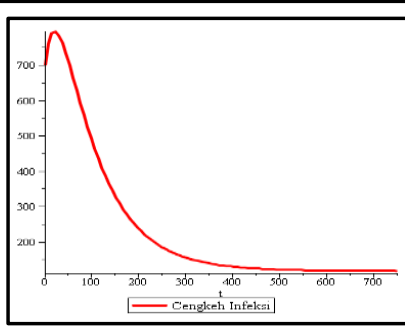

(c)

Gambar 5 : kondisi endemik $T_{4}$

\section{KESIMPULAN}

Berikut ini merupakan beberapa kesimpulan dari hasil penelitian yang telah dilakukan anatara lain sebagai berikut :

1. Model dinamis penyebaran penyakit BPKC pada tanaman cengkeh dapat disusun ke dalam sistem persamaan diferensial sebagai berikut:

$$
\begin{aligned}
& \frac{d B}{d t}=r_{1} B\left(1-\frac{B}{K_{1}}\right) \\
& \frac{d H}{d t}=r_{2} H\left(1-\frac{H}{K_{2}}\right) \\
& \frac{d s_{c}}{d t}=A-\alpha \cdot B \cdot H-\mu_{1} S_{c} \\
& \frac{d E_{c}}{d t}=\alpha \cdot B \cdot H-\delta E_{c}-\mu_{1} E_{c} \\
& \frac{d I_{c}}{d t}=\delta E_{c}-\mu_{2} I_{c}
\end{aligned}
$$

2. Dari model dinamis penyebaran penyakit BPKC pada tanaman cengkeh dapat diperoleh empat titik kritis yang eksis sebagai berikut :

a. Titik kritis $T_{1}$ yang menggambarkan kondisi bebas penyakit yaitu

$$
T_{1}=\left(Z, E_{c}^{*} I_{c}^{*}, B^{*}, H^{*}\right)=\left(\frac{A}{\mu_{1}}, 0,0,0,0\right)
$$

b. Titik kritis $T_{2}$ yang menggambarkan kondisi bebas penyakit yaitu

$$
T_{2}=\left(Z, E_{c,}^{*} I_{c}^{*}, B^{*}, H^{*}\right)=\left(\frac{A}{\mu_{1}}, 0,0, K_{2}, 0\right)
$$

c. Titik kritis $T_{3}$ yang menggambarkan kondisi bebas penyakit yaitu

$$
T_{3}=\left(Z, E_{c,}^{*} I_{c}^{*}, B^{*}, H^{*}\right)=\left(\frac{A}{\mu_{1}}, 0,0,0, K_{1}\right)
$$

d. Titik kritis $T_{4}$ yang menggambarkan kondisi endemik yaitu

$$
T_{4}=\left(Z, E_{c}^{*} I_{C}^{*}, B^{*}, H^{*}\right)=\left(\frac{A-\alpha K_{1} K_{2}}{\mu_{1}}, \frac{\alpha K_{1} K_{2}}{\mu_{1}+\delta}, \frac{\alpha K_{1} K_{2}}{\left(\mu_{1}+\delta\right) \mu_{1}}, K_{1}, K_{2}\right)
$$

e. Analisa terhadap syarat eksistensi dan kestabilan di titik-titik kritis memberikan :

a. Titik kritis bebas penyakit $T_{1}, T_{2}$ dan $T_{3}$ adalah titik kritis tidak stabil sedangkan titik kritis endemik $T_{4}$ stabil.

b. Titik kriti $T_{1}, T_{2}$ dan $T_{3}$ eksis sedangkan titik kritis $T_{4}$ eksis jika memenuhi syarat $\alpha<\frac{A}{K_{1} K_{2}}$ 


\section{DAFTAR PUSTAKA}

[1] Balfas, R ., S.J Eden Green., T, Sutarjo Dan N, Karyani, Karakteristik Perolehan Penularan Pseodomonase Syzygii Nov, Sp. Oleh Hindola Strata. Prosiding kongres nasional X dan seminar ilmiah Perhimpunan Fitopologi Denpasar, 14-16 Nopember 1989, Perhimpunan Fitopologi Indonsia. pp. 408-411.

[2] Eden-Green, S.J., R, Balfas, and T, Sutarjo, Characteristics Of The Transmission Of Sumatra Of Cloves By Tubebuilding Cercopoids, Hindola Spp, Plant Pathol,1992, 41(6): 702-712,

[3] Nurdjannah, N, Diversifikasi Penggunaan Cengkeh, Perspektif 3(2) : 2004, 61-70.

[4] Supriadi, Karakteristik Pseudomonas Solanacearum, P, Syzygii Dan Bakteri Penyebab Penyakit Darah (Blood Disease Bacterium) Pada Pisang, P, 557-581, 1995, Kongres Nasional XIII dan Seminar IImiah Perhimpunan Fitopatologi Indonesia.

[5] Vaneechoutte, M., P. Kampfer., T, De Baere., E. Falsen., \& G, Verscharaegen, Wautersiagen, nov., a Novel Genus Accomodating The Phylogenetic Lineage Including Ralstonia Eutropha And Related Species, And Proposal Of Ralstonia [Pseudomonas] Syzygii (Roberts et al., 1990) comb, nov, International Journal Of Systematic And E Volutionary Microbiology 54: 2004, 31 7-327. 